\title{
INSTITUT ROYAL DU PATRIMOINE ARTISTIQUE RADIOCARBON DATES VII
}

\section{MICHÈLE DAUCHOT-DEHON, JOS HEYLEN, and MARK VAN STRYDONCK}

Institut Royal du Patrimoine Artistique, Brussels, Belgium

This list contains most of the measurements made during 1979, since our last list $(\mathrm{R}, 1979, \mathrm{v} 21, \mathrm{p}$ 180-185). The laboratory procedures were outlined previously ( $R, 1968$, v 10, p 29-34; $R, 1971$, v 13, p 29-31). The collagen extraction follows Longin (1970).

\section{Booitshoeke series}

$$
\begin{gathered}
\text { I. GEOLOGIC SAMPLES } \\
\text { A. Belgium }
\end{gathered}
$$

Alternating clay and peat layers in Western Belgian Coastal plain. Coll and subm 1978 by C Baeteman, Geol Service, Belgium.

IRPA-285. Booitshoeke Zeedijk $1 \quad 2080 \pm 140$

Top of peat layer, $55 \mathrm{~cm}$ thick, at $100 \mathrm{~cm}$ below surface $\left(51^{\circ} 05^{\prime} 38^{\prime \prime}\right.$ $\mathrm{N}, 2^{\circ} 44^{\prime} 05^{\prime \prime} \mathrm{E}$ ).

IRPA-286. Booitshoeke Zeedijk 2 $3740 \pm 140$

Base of peat layer, $55 \mathrm{~cm}$ thick, at $155 \mathrm{~cm}$ below surface $\left(51^{\circ} 05^{\prime} 38^{\prime \prime}\right.$ $\left.\mathrm{N}, 2^{\circ} 44^{\prime} 05^{\prime \prime} \mathrm{E}\right)$.

IRPA-287. Booitshoeke Zeedijk 3

Top of lower peat layer, $40 \mathrm{~cm}$ thick, at $170 \mathrm{~cm}$ below surface $\left(51^{\circ} 05^{\prime}\right.$ $\left.38^{\prime \prime} \mathrm{N}, 2^{\circ} 44^{\prime} 05^{\prime \prime} \mathrm{E}\right)$.

IRPA-288. Booitshoeke Zeedijk 4

Base of lower peat layer, $40 \mathrm{~cm}$ thick, at $210 \mathrm{~cm}$ below surface $\left(51^{\circ} 05^{\prime}\right.$ $38^{\prime \prime} \mathrm{N}, 2^{\circ} 44^{\prime} 05^{\prime \prime} \mathrm{E}$ ).

IRPA-289. Booitshoeke Vaart BH 10

Top of peat layer, $35 \mathrm{~cm}$ thick, at $100 \mathrm{~cm}$ below surface $\left(51^{\circ} 05^{\prime} 25^{\prime \prime}\right.$ $\left.\mathrm{N}, 2^{\circ} 43^{\prime} 50^{\prime \prime} \mathrm{E}\right)$.

IRPA-290. Booitshoeke Vaart BH 11

Base of peat layer, $35 \mathrm{~cm}$ thick, at $135 \mathrm{~cm}$ below surface $\left(51^{\circ} 05^{\prime} 25^{\prime \prime}\right.$ $\mathrm{N}, 2^{\circ} 43^{\prime} 50^{\prime \prime}$ E). Dilution: $30 \%$ sample.

IRPA-291. Booitshoeke Vaart BH 12

Top of lower peat layer, $65 \mathrm{~cm}$ thick, at $200 \mathrm{~cm}$ below surface $\left(51^{\circ} 05^{\prime}\right.$ $25^{\prime \prime} \mathrm{N}, 2^{\circ} 43^{\prime} 50^{\prime \prime} \mathrm{E}$ ).

IRPA-292. Booitshoeke Vaart BH 13

Base of lower peat layer, $65 \mathrm{~cm}$ thick, at $265 \mathrm{~cm}$ below surface $\left(51^{\circ} 05^{\prime}\right.$ $25^{\prime \prime} \mathrm{N}, 2^{\circ} 43^{\prime} 50^{\prime \prime} \mathrm{E}$ ). 


\section{Avekapelle series}

Peat layer in Western Belgian Coastal plain from 115 to $300 \mathrm{~cm}$ below surface $\left(51^{\circ} 04^{\prime} 44^{\prime \prime} \mathrm{N}, 2^{\circ} 45^{\prime} 25^{\prime \prime} \mathrm{E}\right)$. Coll and subm by C Baeteman.

IRPA-334. Avekapelle 32-35

$3450 \pm 180$

Sample 175 to $185 \mathrm{~cm}$ below surface.

IRPA-335. Avekapelle 25-28

$4240 \pm 190$

Sample 205 to $215 \mathrm{~cm}$ below surface.

IRPA-336. Avekapelle 58-60

$3340 \pm 170$

Sample 130 to $140 \mathrm{~cm}$ below surface.

General Comment: ages of first end of peat growth in Booitshoeke and beginning of wetter conditions in Avekapelle agree well. Age of second start of peat growth and end of wet conditions seriously disagree. Age of top is nearly identical in Booitshoeke Vaart and Avekapelle, and is similar with IRPA-283, -337, and -338 (Baeteman et al, 1979).

IRPA-333. Whale bone

B. North Sea

Whale bone (Exchrichtus gibbosus) found at bottom of North $\left(51^{\circ} 30^{\prime} \mathrm{N}, 0^{\circ} 42^{\prime} \mathrm{E}\right)$. Coll 1978 by N Craps and subm $1979 \mathrm{~W}$ Desmedt, Inst Royal Sci Nat, Belgium. Comment: sample washed with $25 \% \mathrm{HCl}$; dated with carbonate because of insufficient collagen.

\section{Namib-Erongo series}

\section{Southeast Africa}

Calcareous rock from East Africa. Samples were washed with $25 \%$ HC1 until $50 \%$ loss of material. Coll 1974 and subm 1977 by W D Blümel, Geol Inst, Univ Karlsruhe, West Germany.

IRPA-275. Namib 51a

$21,300 \pm 570$

Carbonate from layer in Namib reserve $\left(24^{\circ} \mathrm{S}, 16^{\circ} \mathrm{E}\right)$, alt $+900 \mathrm{~m}$.

IRPA-276. Namib 44a

$>45,000$

Carbonate nodules and sand from layer in Namib reserve $\left(24^{\circ} \mathrm{S}, 16^{\circ}\right.$ $\mathrm{E})$, alt $+900 \mathrm{~m}$.

IRPA-277. Erongo 98a

$19,600 \pm 470$ $1200 \mathrm{~m}$

Carbonate from layer on Erongo Mt $\left(21^{\circ} 30^{\prime} \mathrm{S}, 15^{\circ} 20^{\prime} \mathrm{E}\right)$, alt +

IRPA-278. Erongo 95

$29,900 \pm 660$ $1200 \mathrm{~m}$.

Carbonate from layer on Erongo Mt $\left(22^{\circ} 30^{\prime} \mathrm{S}, 15^{\circ} 20^{\prime} \mathrm{E}\right)$, alt +

General Comment: dates agree with expected age. 


\section{ARCHAEOLOGIC SAMPLES}

\section{Leffinge series}

$$
\text { A. Belgium }
$$

Multidisciplinary study on Roman saltmaking furnaces at Leffinge in Belgian Coastal plain ( $51^{\circ} 08^{\prime} \cdot 40^{\prime \prime} \mathrm{N}, 2^{\circ} 52^{\prime} 13^{\prime \prime} \mathrm{E}$ ). Coll July 1978 by C Baeteman, C Verbruggen, and H Thoen; subm 1978 by C Baeteman.

IRPA-282. LFZ 78/27/15

$4470 \pm 220$

Base of peat layer, $40 \mathrm{~cm}$ thick, at $120 \mathrm{~cm}$ below surface.

IRPA-283. LFZ 78/15/24 Oven XII

$3140 \pm 170$

Top of peat layer, $40 \mathrm{~cm}$ thick, underlying Furnace XII, at $80 \mathrm{~cm}$ below surface.

IRPA-284. I LFZ 78/17/a

$$
2380 \pm 130
$$

IRPA-284. II

$$
2120 \pm 120
$$

Ashes from furnace, from center of layer, $25 \mathrm{~cm}$ thick, at $85 \mathrm{~cm}$ below surface. Comment: I and II are two fractions of same sample.

IRPA-337. LFZ A.Peat

$$
3340 \pm 190
$$

Top of same peat layer as IRPA-283. Dated to compare with palynologic analysis.

\section{IRPA-338. LFZ A-Wood}

Wood in same peat layer as IRPA-337.

General Comment: dates of top and base agree with Antw-227, -102, and -249 (Vanhoorne and Van Dongen, 1976; Vanhoorne, Van Strydonck, and Dubois, 1978). Expected date for IRPA-284 was 1700 BP; radiocarbon dating reveals that furnace fuel was probably a mixture of Roman-age material (wood) and peat. The peat layer under furnaces was not disturbed.

IRPA-346. Bredene

$$
460 \pm 90
$$

Human bones from excavation at Bredene $\left(51^{\circ} 14^{\prime} 43^{\prime \prime} \mathrm{N}, 2^{\circ} 57^{\prime}\right.$ $11^{\prime \prime}$ E), at $80 \mathrm{~cm}$ depth. Coll 1976 by R Eeckhout and subm 1979 by $\mathrm{H}$ Thoen, Univ Gent, Belgium. Comment: dated with collagen; no archaeol data.

\section{Dinant series}

Human bones from excavation in transept of collegiate church in Dinant $\left(50^{\circ} 15^{\prime} 44^{\prime \prime} \mathrm{N}, 4^{\circ} 54^{\prime} 50^{\prime \prime} \mathrm{E}\right)$. Coll Sept 1978 by M Osterrieth and subm 1979 by $P$ Bonenfant, Univ Libre, Brussels, Belgium.

IRPA-293. Dinant I

$$
780 \pm 40
$$

IRPA-294. Dinant II

$$
830 \pm 50
$$

General Comment (PB): dates confirm expected age between 11 th and 13 th centuries. 
IRPA-220. Liège $\mathbf{n}^{\circ} 5$

$1100 \pm 230$

Wood from excavation at Liège $\left(50^{\circ} 30^{\prime} 51^{\prime \prime} \mathrm{N}, 5^{\circ} 34^{\prime} 45^{\prime \prime} \mathrm{E}\right)$. Coll 1974 and subm 1979 by M Otte, Serv Archeol Prehist, Univ Liège, Belgium. Comment: date agrees with archaeol data.

\section{Tell ed-Dér series}

$$
\text { B. Asia }
$$

Samples in muddy clay from occupied ground of tell, alt 36 to $37 \mathrm{~m}$, at Tell ed-Dér, Iraq $\left(33^{\circ} 05^{\prime} 08^{\prime \prime} \mathrm{N}, 44^{\circ} 14^{\prime} 35^{\prime \prime} \mathrm{E}\right)$. Coll 1975 by $\mathrm{H}$ Gasche and subm 1979 by L De Meyer, Seminar Archeol, Univ Gent, Belgium. Comment: samples with $(\mathbf{P})$ were indurated with Paraloid which was removed by dry distillation. These dates complete those published in R, 1979, v 21, p 180-185.

IRPA-304. DPr 509

$$
4070 \pm 230
$$

Burned wood (Populus) from Layer 21.3.1, Boring E.

IRPA-305. DPr 531 (P)

Burned wood (Populus and Pinus) from Layer 22.3.1, Boring E.

IRPA-306. DPr 532 (P)

$4160 \pm 210$

Burned wood (Populus) from Layer 15.3.1, Boring E.

IRPA-307. DPr 533

Burned wood (Populus) from Layer 21.3.1, Boring E.

$$
5180 \pm 250
$$

IRPA-309. DPr 535 (P)

Wood and clay from Layer 22.3.1, Boring E.

$$
3910 \pm 200
$$

IRPA-310. DPr 584

Burned wood from Layer 27.3.1, Boring E.

$4010 \pm 200$

\section{Apamee series}

Animal bone and charcoal fragments from occupied ground of tell, alt $210 \mathrm{~m}$, at Qal at el-Mudiq (Hama), Syria $\left(35^{\circ} 25^{\prime} \mathrm{N}, 36^{\circ} 24^{\prime} \mathrm{E}\right)$. Coll 1974 and subm 1976 by J Balty, Mus Royaux Art et Hist, Brussels, Belgium.

IRPA-205. AP. 74. III. 1.1

$$
1400 \pm 80
$$

Bone fragments from Room $\mathrm{E}$.

IRPA-206. AP. 74. III. 2

$$
580 \pm 30
$$

Bone fragments from Room F.

$$
1090 \pm 80
$$

Bone fragments under Column C19.

$$
1280 \pm 70
$$

\footnotetext{
Bone fragments from second floor, C12-C13.
} 
IRPA-210. AP. 74. III. 30

$910 \pm 70$

Bone fragments.

IRPA-212. AP. 75

$1310 \pm 80$

Charcoal from E Cathedral.

IRPA-213. AP. 74. V. 5, 6 and 15

$3500 \pm 170$

Bone fragments from Layer III.

IRPA-214. AP. 74. V. 8.3

$3200 \pm 150$

Bone fragments from Hole 2.

IRPA-215. AP. 74. V. 7.3

Bone fragments from Hole 1.

$3710 \pm 210$

General Comment: dates agree with archeol data: coins and ceramics. IRPA-213, -214, and -215 dated with carbonate because of insufficient collagen; dates are too young, probably because of carbonate contamination.

\section{REFERENCES}

Baeteman, C, Verbruggen, C, with Dauchot-Dehon, M, Heylen, J, and Van Strydonck, M, 1979, New approach to the evolution of the so-called surface peat in the Western Coastal plain of Belgium: Geol Service Belgium, Prof Paper, 11, no. 167.

Longin, R, 1970, Extraction du collagène des os fossiles pour leur datation par la méthode du carbone-14: Thesis, Fac Sci, Univ Lyon, France.

Vanhoorne, R and Van Dongen, W, 1976, Antwerp University radiocarbon dates I: Radiocarbon, v 18, p 151-160.

Vanhoorne, R, Van Strydonck, $\mathbf{M}$, and Dubois A, D, 1978, Antwerp University radiocarbon dates III: Radiocarbon, v 20, p 192-199. 